\title{
Kegiatan Bina Lingkungan Terhadap Pandemi Covid-19 di Lingkungan Kampus Akademi Penerbang Indonesia Banyuwangi
}

\author{
Ahmad Hariri ${ }^{1}$, Genny Luhung $P^{2}$, Prasetyo Iswahyudi ${ }^{3}$, Ikhwanul Qiram ${ }^{4 \bowtie}$ \\ 1,2,3 Akademi Penerbang Indonesia, Banyuwangi \\ ${ }^{4}$ Program Studi Teknik Mesin, Fakultas Teknik, Universitas PGRI Banyuwangi \\ Email: hazul50@gmail.com ${ }^{1}$, gprasojo@gmail.com², mrprasetyo25@gmail.com ${ }^{3}$, \\ ikhwanulqiram@gmail.com ${ }^{4}$
}

\begin{abstract}
Abstrak - Penularan Covid-19 saat ini terus meningkat secara drastis di berbagai negara terutama di Indonesia. Rendahnya pengetahuan serta penggunaan APD akan memicu grafik penularan terus meningkat. Tujuan kegiatan ini adalah memberikan edukasi mengenai resiko penyebaran dan penularan virus serta langkah penanganan pencegahan terhadap Covid-19. kegiatan dilakukan dengan memberikan edukasi langsung ke masyarakat dan pemberian bantuan masker serta bahan pokok. Proses edukasi dilakukan dengan menunjukkan media penularan berupa poster agar lebih mudah dipahami dengan baik. Hasil dari kegiatan pengabdian ini adalah terbentuknya pengetahuan yang baik dari masyarakat serta mampu menerapkan pencegahan Covid-19 serta melakukan kebiasaan perilaku hidup bersih dan sehat dalam beraktifitas setiap harinya. Kata kunci : Covid19, Sosialisasi, Edukasi
\end{abstract}

Kata Kunci - Covid-19, Bina Lingkungan, Edukasi, Pengabdian Kepada Masyarakat

Abstract - The current Covid-19 transmission continues to increase drastically in various countries, especially in Indonesia. Low knowledge and use of PPE will trigger the transmission graph to continue to increase. The purpose of this activity is to provide education about the risk of spreading and spreading the virus and taking preventive measures against Covid-19. activities carried out by providing direct education to the community and providing masks and staple goods. The educational process is carried out by showing the transmission media in the form of posters so that it is easier to understand properly. The result of this service activity is the formation of good knowledge from the community and being able to implement Covid-19 prevention and to adopt clean and healthy habits in their daily activities. Keywords: Covid-19, Socialization, Education

Keywords - Covid-19, Community Development, Education, Community Service

\section{Pendahuluan}

Wabah Corona virus Disease 2019 (COVID-19) telah melanda seluruh penjuru dunia. Banyak negara yang berusaha menanggulangi penyebaran wabah tersebut dengan melakukan contact tracing. Sejauh ini belum tersedia pengobatan yang efektif, metode terbaik untuk menangani epidemi SARS-CoV-2 adalah mengendalikan sumber infeksi [1]. Berbagai metode penelusuran dilakukan sebagai bagian dari upaya untuk menekan epidemi. Akan tetapi, aktifitas sosial masyarakat dan sifat dari COVID-19 yang sangat menular membuat upaya contact tracing menjadi sulit dilakukan [2].

Sebagai salah satu Perguruan Tinggi Negeri dari Kementrian Perhubungan yang berada di Kabupaten Banyuwangi. API Banyuwangi adalah organisasi yang mengajarkan bagaimana sistem keamanan dan keselamatan menjadi pengetahuan penting yang harus dimiliki oleh taruna. Hal ini terlihat bagiamana respon Pemerintah melalui Ditjen Perhubungan Udara menetapkan sistem keamanan pada transportasi udara.
Penerapan sistem keamanan terpadu termasuk juga menjadi bagian kegiatan Bina Lingkungan. Program Bina Lingkungan adalah program pemberdayaan kondisi sosial masyarakat di sekitar wilayah operasi [3].

Sebagai bagian dari fungsi Tridharma Perguruan Tinggi, API Banyuwangi juga berkawijan untuk memberikan tindak lanjut terhadap pencegahan penyebaran Covid-19 sebagaimana termaktub dalam SE Menteri Perhubungan No4 Tahun 2020 [4]. Langkah program bina lingkungan dilakukan dengan memberikan pemahaman pada masyarakat di lingkungan sekitar Institusi API Banyuwangi. Kegiatan ini bertujuan untuk membantu meringankan beban masyarakat yang terdampak wabah Covid-19, sehingga IPTEK yang diberikan juga disertai dengan pendistribusian bantuan bahan pokok pada masyarakat dilingkungan API Banyuwangi.

\section{SOLUSI DAN LUARAN}

Ditengah aktifitas sosial masyarakat sekitar Kecamatan Rogojampi yang cukup tinggi, dipandang 
penting untuk sesegra kelompok masyarakat terdampak ini diberikan pemahaman tentang bahaya Covid-19 serta tata cara pencegahan minimal. Selain itu, masyarakat juga diberikan bahan penunjang sebagai upaya untuk menjaga nutrisi mereka serta keluarga yang terdampak agar meminimalisir resiko tertular akibat penurunan daya tahan tubuh.

\section{METODE KegiatAN}

Kegiatan pelatihan ini dilakukan bertempat di beberapa spot penting yang meliputi :

1. Desa Gitik dan Jagalan

2. Desa Badean

3. Desa Blimbingsari dan Patoman

4. Pasar Banyuwangi Kota

5. Desa Kabat

6. Pasar Srono

7. Posko Bina Lingkungan API Banyuwangi

Kegiatan dilakukan selama 9 hari sejak tanggal 1 hingga 9 April 2020. Sosialisasi dilakukan saat bersamaan dengan serah terima bantuan bahan pokok melalui panitia yang telah diberikan wawasan dan kecukupan media APD dalam pelaksanaan kegiatan lapangan.

\section{Hasil Kegiatan}

Kegiatan dilaksanakan secara langsung dengan menerjunkan sejumlah tim ke lapangan. Dimana kegiatan ini telah dikordinasikan dengan stakeholder atau pemangku wilayah setempat sehingga memudahkan proses pelaksanaan dengan tetap mematuhi protocol kesehatan. Informasi yang diberikan berupa penggunaan masker, menjaga jarak, rajin membersihkan diri dengan cara cuci tangan dan mandi secara teratur.
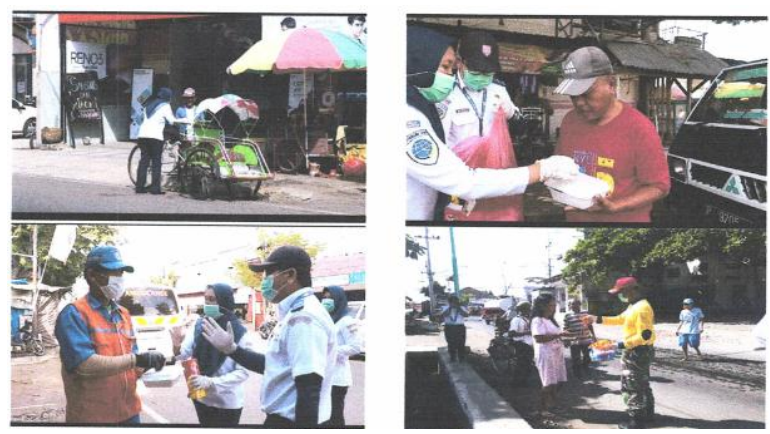
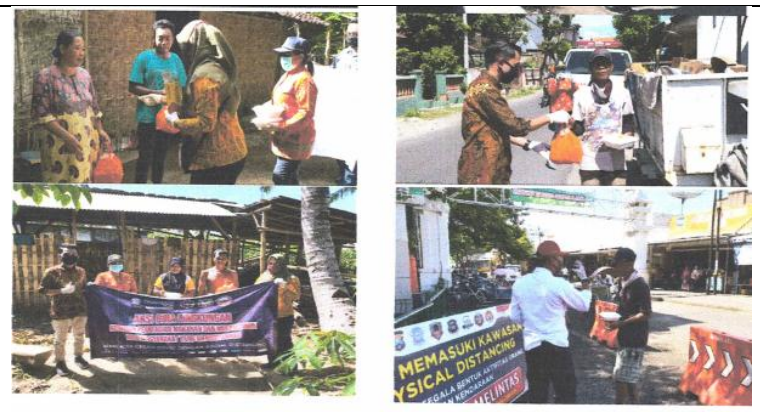

Gambar 1. Dokumentasi kegiatan

Melalui kegiatan ini, masyarakat juga memberikan respon positif. Hal ini menjadi penting terutama disaat aktifitas ekonomi yang mereka lakukan. Melalui kegiatan di 7 titik penting dengan potensi kerumunan massa yang tinggi, diharapkan kegiatan ini dapat memberikan efek sosiologis yang baik.

\section{KESIMPULAN}

Dampak buruk pandemi telah memberikan efek sosial yang cukup tinggi. Disaat beraktifitas ekonomi, masyarakat butuh kesiapan diri untuk menjaga diri dari bahaya penularan Covid-19. Melalui pengetahuan dan penggunaan APD serta perubahan perilaku yang sehat dan bersih diharapkan akan menekan laju pandemi di Kabupaten Banyuwangi pada umumnya.

\section{UCAPAN TERIMA KASIH}

Ucapan terimakasih disampaikan kepada Direktur API Banyuwangi serta UPPM dan segenap jajaran API Banyuwangi melalui dukungan yang diberikan dalam Program Kemitraan bagi Masyarakat tahun 2020.

\section{DAFTAR PUSTAKA}

[1]. Celine Grace (2020) Manifestasi Klinis dan Perjalanan Penyakit pada Pasien Covid-19. Majority, Volume 9 Nomor 1

[2]. Muhammad Aliffiro Naufal, Nur Aini Rakhmawati (2020) Analisis Privasi Data Pengguna Aplikasi Tracing COVID-19. https://www.researchgate.net/publication/341574 087, DOI: 10.13140/RG.2.2.28050.27840

[3]. Bina Lingkungan, https://pertamina.com/id/binalingkungan\#: :text=Program $\% 20 \mathrm{Bina} \% 20 \mathrm{Lingk}$ ungan \%20adalah\%20program,2\%25\%20dari\%20 Prognosa\%20laba\%20peusahaan, Disadur tanggal 18 April 2020, 12:08 WIB

[4]. Surat Edaran Menteri Perhubungan Nomor 4 Tahun 2020, Tentang Tindak Lanjut Pencegahan Penyebaran Corona Virus Disease 2019 (COVID19) dilingkungan Kementrian Perhubungan 